\title{
Yod
}

Revue des études hébraïques et juives

$23 \mid 2021$

Le Voyage de l'hébreu à travers le temps et la société

\section{Bridge over Troubled Water: Spelling Accuracy of Novel Phonemes in Arabic among Native Hebrew-Speaking Pupils in a Bilingual- Arabic-Hebrew-Elementary School}

Un pont au-dessus d'une eau trouble : l'épellation de phonèmes arabes inconnus parmi des locuteurs natifs de l'hébreu dans une école élémentaire bilingue

(hébreu-arabe)

גשר צר מאוד:איות פונמות לא מוכרות בערבית בקרב דוברי עברית כשפת

אם בבית הספר היסודי הדו-לשוני (ערבית-עברית)

\section{Alon Fragman and Aura Mor-Sommerfeld}

\section{(2) OpenEdition}

\section{Journals}

Electronic version

URL: https://journals.openedition.org/yod/5253

DOI: $10.4000 /$ yod. 5253

ISSN: 2261-0200

Publisher

INALCO

Printed version

Date of publication: 6 May 2021

Number of pages: $223-245$

ISBN: 978-2-85831-380-8

ISSN: 0338-9316

Electronic reference

Alon Fragman and Aura Mor-Sommerfeld, "Bridge over Troubled Water: Spelling Accuracy of Novel Phonemes in Arabic among Native Hebrew-Speaking Pupils in a Bilingual-Arabic-Hebrew-

Elementary School", Yod [Online], 23 | 2021, Online since 15 April 2021, connection on 08 July 2021. URL: http://journals.openedition.org/yod/5253 ; DOI: https://doi.org/10.4000/yod.5253

This text was automatically generated on 8 July 2021.

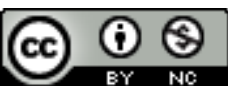

Yod est mis à disposition selon les termes de la Licence Creative Commons Attribution - Pas d'Utilisation Commerciale 4.0 International. 


\section{Bridge over Troubled Water: Spelling Accuracy of Novel} Phonemes in Arabic among Native Hebrew-Speaking Pupils in a Bilingual-Arabic-HebrewElementary School

Un pont au-dessus d'une eau trouble : l'épellation de phonèmes arabes inconnus parmi des locuteurs natifs de l'hébreu dans une école élémentaire bilingue (hébreu-arabe)

גשר צר מאוד:איות פונמות לא מוכרות בערבית בקרב דוברי עברית כשפת

אם בבית הספר היסודי הדו-לשוני (ערבית-עברית)

Alon Fragman and Aura Mor-Sommerfeld

\section{Introduction'}

1 Two core issues are at the heart of this paper. The first deals with bilingual education; the second refers to the acquisition of novel phonemes and phoneme-grapheme correspondences. Both are integrated in the pedagogical setting of a bilingual school in Israel.

2 Although some encounter points as hospitals, shopping centers or sports, most Arabic and Hebrew populations in Israel have separate community life and live in separate cities and/or neighbourhoods. Further, under the control and supervision of the Ministry of Education, educational systems for Arabic and Hebrew speakers are also separate. ${ }^{2}$ This separation has given rise to mutual hatred, fear, prejudice, distrust, and stereotyping of "the other." ${ }^{3}$ Not a few Hebrew L1 pupils express hostility and 
objections to learning Arabic, mostly during periods of political tension, so that teaching Arabic in the Hebrew-Jewish sector presents considerable challenges. This may also explain why most of studies conducted over the past twenty years in the Hebrew sector focus mainly on pupils' attitudes, and only a few explore the linguistic aspects. ${ }^{4}$

3 As a rule, education in Israel is divided into one system for Hebrew L1 speakers, and the second for Arabic L1 speakers. Hebrew and Arabic are both official languages in Israel, de jure; but the de facto hierarchy situates Hebrew as the majority language and Arabic as the minority language. ${ }^{5}$ Thus, while all Arabic schools are obliged to teach Hebrew as a second language from $2^{\text {nd }}$ or $3^{\text {rd }}$ grade, Hebrew schools do not have to teach Arabic. If they do so, it is either in order to "know the enemy"' or as a cultural approach rather than a linguistic achievement, thereby maintaining the policy of segregation and preserving the general atmosphere of hostility and frustration. Obviously, this dichotomy reflects both the majority-minority conflict of the two populations as well as the language-power relationship.

4 However, a small nucleus of bilingual schools has been established in Israel, not merely for linguistic purposes. These Arabic-Hebrew schools have been established in an attempt to create practices of partnership between two nations that are in geopolitical and socio-historical conflict. ${ }^{7}$ Perhaps this is why studies in these schools have focused mainly on social and socio-political aspects-the ecology of the schools, the parents, teachers, and general pedagogy. The present study focuses on some of the linguistic elements and is intended to expand the general body of knowledge of the subject.

\section{Arabic-Hebrew bilingual schools in Israel}

Bilingual education in Israel has been promoted mostly by non-governmental organizations (NGOs) and by individuals. Wahat al-Salam/Neve Shalom was the first bilingual school, founded in 1984. Others were opened by the Hand-in-Hand Centre for Jewish-Arab Educationin the Galilee, in Jerusalem and, in cooperation with the Bridge across the Wadi Fellowship, in Wadi Ara. Today, three more schools and kindergartens are operating in the Jezebel Valley, Be'er Sheva, and Haifa, and others are being considered by individuals and NGOs alike. All Arabic-Hebrew schools are recognized by the Ministry of Education, and the pupils learn according to the official Educational syllabus and textbooks.

6 These schools provide bilingual, bicultural and bi-national settings in which pupils learn together on a daily basis. ${ }^{8}$ They offer a setting for interaction between Arabic L1 and Hebrew L1 speakers, and for both languages to be taught on a relatively equal footing. ${ }^{9}$ Moreover, according to the cultural-cognitive model for bilingual education, ${ }^{10}$ Arabic and Hebrew L1 teachers work as a team, each class having Arabic and Hebrew L1 home teachers (mainly in the elementary grades). Also, most lessons are conducted by native teachers, each speaking and teaching his/her L1. ${ }^{11}$ Efforts are made to enrol approximately equal numbers of Arabic and Hebrew speaking children and to emphasize the symmetry between the two languages. ${ }^{12}$

7 As stated earlier, previous studies of Arabic-Hebrew schools in Israel essentially focused on educational and social aspects of mutual learning, and the attitudes of the participants from both populations to their counterparts and the school system. ${ }^{13}$ These studies found positive attitudes towards self and others' identity. ${ }^{14}$ Shared 
interests of Arab and Hebrew L1 partners in the framework of bilingual education have also developed mutual and positive attitudes towards others' language, culture and history. ${ }^{15}$ However, even in the bilingual setting, Hebrew is still the dominant language. ${ }^{16}$ Bilingual individuals are expected to speak two (or more) languages to some level of proficiency, ${ }^{17}$ but the Hebrew L1 students seemed to lack the proficiency needed for daily communication in Arabic even in the bilingual setting. ${ }^{18}$ A recent study conducted in bilingual schools focused on speed and accuracy in reading Arabic and Hebrew texts, ${ }^{19}$ but without reference to the pedagogical setting. Thus, it is the results of the current study that may shed light on the pedagogical model adopted by Neve Shalom/ Wahat al-Salam during the years 2012-2014, and on its contribution to Arabic-Hebrew bilingualism.

\section{The pedagogical setting of Neve Shalom/ Wahat al-Salam}

Generally speaking, there are two main pedagogical approaches to language instruction in the Arabic-Hebrew bilingual school. The first is the subject-based curriculum, imparting a language through a variety of subjects; the second is according to language learning (L1 \& L2) methods (i.e. formal Arabic lessons, as well as Hebrew ones, are taught in all grades). Both approaches operate according to the "no translation" and "no separation" principle, to Arabic and Hebrew L1 learners alike. Thus, for the first option (the subject-based curriculum), two teachers, L1 Arabic and L1 Hebrew, would impart the lesson. For the second option (language learning method), two teachers with the same first language (AL1 or HL1) conduct the lessons, mainly in the lower grades. The intention is to establish both languages in the early years, so that only one teacher is required for the upper grades later on. What makes the second approach unique is the presence of two L1 teachers. This enables a mode of communication between the teachers (not all of the Hebrew-Jewish teachers speak Arabic). This is rather different from the "standard" classroom, in which communication (if any) is just between the teacher and the pupils (and/or the pupils themselves).

Regarding which is the more suitable model for the bilingual school: over the years, the Oasis of Peace School has implemented various bilingual teaching programmes in order to adopt the most satisfactory system for the school. Among them were different methods of language instruction, including a period of separate classes in Arabic and Hebrew as first and/or second language. This meant that, for part of the day, and mainly for language instruction, children learnt only or mostly together with other native-language speakers. This obviously reduced opportunities to hear and/or talk in the other language.

10 A few years ago, the school adopted what we defined as the "second model" for the First Grade, focusing on (i) the language of instruction ("no translation"), (ii) no separation between L1 Hebrew and Arabic native speaking children, and (iii) two native Arabic (or Hebrew) speaking teachers in the classroom. However, the school's pedagogy at the time of our study can be defined as a combined model of the two methods. For the last few years, pupils have been learning together in Arabic or Hebrew, developing their language skills using both L1 and L2 methods: learning the language/s and learning through direct instruction in both languages. Thus, the two models are interwoven to form a combination of content-based curricula and language learning-teaching. 


\section{Linguistic outcomes in bilingual education}

There are linguistic advantages in bilingual education. However, for children who are only partially bilingual, different levels of second language proficiency were observed among different groups. ${ }^{20}$ Other studies found different patterns of emerging phonological awareness for children whose languages were English and Spanish ${ }^{21}$ than that for children whose languages were English and Chinese. ${ }^{22}$ The researchers suggested that these differences were the outcome of the two languages spoken by the children. It had also been suggested that children who speak a second language with similar phonological structure and alphabetic orthographic systems to their native tongue may have some advantage over monolingual children when learning to read in their L1. ${ }^{23}$ Common to all the studies examining various linguistic aspects, such as word awareness, syntactic awareness, and phonological awareness, advantages to bilinguals were observed in certain tasks, and disadvantages in other tasks. It should be borne in mind that various factors intervene in these processes of language acquisition, such as the cognitive stage of the child, the relation between the two languages, and the pupil's relative proficiency in each language. ${ }^{24}$ However, strong bilingual education programmes ${ }^{25}$ that actively promote learning of and in L1 and L2 facilitate language and literacy, and positively impact cognitive development. ${ }^{26}$

\section{Acquisition of novel phonemes and phoneme-grapheme correspondences}

Over the years, studies have indicated that the phonological skill is a crucial precondition for reading at the beginner stage ${ }^{27}$ and in determining later reading ability in English, ${ }^{28}$ as well as in other languages such as Dutch, ${ }^{29}$ Spanish $^{30}$ and Portuguese. ${ }^{31}$ Other studies showed that phonological processing skills are imperative for becoming a skilled reader, ${ }^{32}$ specifically in alphabetic orthographies. ${ }^{33}$ Studies from various languages, including Arabic, ${ }^{34}$ Portuguese,${ }^{35}$ Chinese ${ }^{36}$ and Japanese,${ }^{37}$ indicated that phonological processing is necessary for any form of visual information processing, including new word learning ${ }^{38}$ and advanced language acquisition. Thus, in learning an additional language, it is highly important to explore the acquisition of novel phonemes-those that do not exist in one's native phonological system.

\section{Arabic novel phonemes: acquisition among Hebrew L1 pupils}

Recent studies of the acquisition of novel phonemes in Arabic among native Hebrew pupils in junior high schools in Israel indicated that native Hebrew pupils had extremely low proficiency in spelling, with no significant improvement even after four years of learning Arabic ${ }^{39}$ In addition, the results indicated a decrease in auditory discrimination proficiency of Arabic sounds over time. This is surprising since one could have expected that Arabic would be easily learned by native Hebrew speakers since both Hebrew and Arabic are Semitic languages and share linguistic similarities. ${ }^{40}$ A possible explanation for these results was insufficient exposure to the language. ${ }^{41} \mathrm{On}$ the average, pupils learn for 3-4 years, from seventh to ninth or tenth grade, three hours per week, i.e. some 90 hours per annum-a total of 360 hours in four years 
of Arabic studies. In comparison, the European average for high-school learning of an additional language is 800 hours. ${ }^{42}$ Moreover, most of the Hebrew L1 Arabic teachers speak Hebrew during Arabic lessons due to inadequate Arabic proficiency. ${ }^{43}$ Some teachers admitted to finding it difficult to pronounce novel Arabic phonemes, therefore avoiding use of Arabic during their lessons, or using it improperly. ${ }^{44}$

However, none of the above-mentioned studies took place in a bilingual setting in which language acquisition occurs inside and outside the classroom, both formally and informally. This study explores the first stages of Arabic acquisition among native Hebrew pupils, focusing on phonological aspects and phoneme-grapheme correspondences of spelling of unfamiliar phonemes in Arabic in an Arabic-Hebrew school. It is the first of a series of studies focusing on linguistic outcomes in Arabic-Hebrew bilingual schools in Israel, and focuses specifically on guttural $(/ \mathrm{H} /)$, uvular_velar (/q/ and / $/ \mathrm{b} /)$, and emphatic (/s/) phonemes.

\section{Research questions}

15 This study set out to explore the spelling accuracy of novel phonemes in Arabic among native Hebrew pupils learning in an Arabic-Hebrew school in second, third, and fourth grades. The research questions were:

- How accurate is the spelling of novel phonemes among native Hebrew-speaking pupils in an Arabic-Hebrew school in the elementary $\left(2^{\text {nd }}, 3^{\text {rd }}\right.$, and $\left.4^{\text {th }}\right)$ grades?

-What is the accurate-spelling level of four novel phonemes targeted for this study (guttural: /H/, uvular-velar: /q/ and /в/, and emphatic: /s/) among those pupils?

\section{Methodology}

Data were collected in Neve Shalom in June 2013. Although the study primarily focused on native Hebrew speakers, the tasks were also administered to their Arab L1 classmates by both researchers during a 45-minute lesson in each class. Within each grade $\left(2^{\text {nd }}, 3^{\text {rd }}\right.$, and $4^{\text {th }}$ grade), the order of administration was rotated in order to control for order effects that might result from each participant doing the tasks in the same order. All tasks were explained by the researcher. Permission for the study was obtained from the school administration.

Four tasks were developed for the study:

1. Real word recognition: This task comprised 20 word pairs in which the examinees were required to recognize correctly spelled words from pairs of words in which one word was spelled correctly and the other incorrectly. These pairs involved changing one letter in a word familiar to the pupils from the Arabic textbook. Construction of different word pairs was based on replacement of one letter which represents a novel phoneme (such as /s/) with a similar phoneme in Arabic that also exists in Hebrew (such as /s/), for example /sawm/-/ sawm/ [fast]. This taps into both phonological and orthographic processes: phonological representation, orthographic knowledge, and phoneme-grapheme correspondences. (Cronbach's Alpha: .82)

2. Auditory discrimination of pseudo-words: this task comprised of 20 pairs of pseudo-words. Participants were required to listen to a pair of pseudo-words, decide whether they were the same or different, and circle their answer on an answer sheet. The pseudo-words were constructed by changing one phoneme from a familiar word. Construction of different word 
pairs was based on pairs of sounds, in which one was a familiar phoneme from Hebrew and the other was a novel phoneme from Arabic, e.g. /wakad/, /waqad/. This is in order to focus the participant's attention on sound recognition without depending on lexical clues, and test their ability to distinguish between sounds that are phonemically similar without an orthographic confound. Each pair of words was heard only once. This taps into the quality of the phonological representation of specific tagged phonemes in the target language. The quality of phonological representations affects the construction of accurate phoneme-grapheme correspondences. (Cronbach's Alpha: .7)

3. Pronunciation discrimination of written pseudo-words: Participants were required to recognize the correct pronunciation of 20 written pseudo-words. For each written word, two pronunciations were heard; one correct and the other incorrect. Each pair was constructed by changing one novel phoneme for a similar phoneme in Arabic which also exists in Hebrew. For example, for the written pseudo-word صَرْب two pronunciations were read aloud: (/sarb/ and /sarb/). Participants were asked to mark the correct pronunciation on their answer sheet. Each pronunciation was heard once. This task is also comprised of pseudo-words in order to focus the participant's attention to sound recognition without depending on lexical clues, and taps into both phonological and orthographic processes: phonological representation, orthographic knowledge, and grapheme-phoneme correspondences. (Cronbach's Alpha: .83)

4. Spelling-to-sound correspondences of written pseudo-word pairs-this task consisted of 20 pairs of written pseudo-words. Participants heard one word from each pair, and were asked to mark on the answer sheet which of the words was read aloud. Construction of different written word pairs was based on pairs of sounds, in which one was a familiar phoneme from Hebrew and the other a novel phoneme from Arabic. For example, of the قَمْش (/qams/) and كَمْس (/kams/), only one was read aloud, and pronounced only once. This task taps into both phonological and orthographic processes: phonological representation, orthographic knowledge, and spelling-to-sound correspondences. (Cronbach's Alpha: .7)

\section{Results}

This study explored the spelling accuracy of novel phonemes in Arabic among 41 native Hebrew pupils learning in a bilingual Arabic-Hebrew elementary school in the second $(\mathrm{N}=13)$, the third $(\mathrm{N}=15)$, and the fourth grade $(\mathrm{N}=13)$, boys $(\mathrm{N}=26)$ and girls $(\mathrm{N}=15)$.

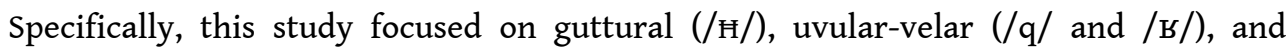
emphatic (/s/) novel phonemes.

The first question considered the overall accuracy of Arabic spelling among the native Hebrew-speaking participants. Table 1 presents descriptive statistics of performance across grades for all tasks for Hebrew L1 pupils. Table 2 presents descriptive statistics of performance among Arabic L1 pupils.

\begin{tabular}{|l|l|l|l|}
\hline & $\begin{array}{l}2^{\text {nd }} \text { grade M } \\
(\mathrm{SD})\end{array}$ & $\begin{array}{l}3^{\text {rd }} \text { grade M } \\
(\mathrm{SD})\end{array}$ & $\begin{array}{l}4^{\text {th }} \text { grade M } \\
(\mathrm{SD})\end{array}$ \\
\hline Real word recognition & $74.61(14.78)$ & $78.37(17.89)$ & $66.53(20.35)$ \\
\hline Auditory discrimination of pseudo-words & $81.62(16.25)$ & $77.77(13.02)$ & $81.19(7.36)$ \\
\hline Pronunciation of written pseudo-words & $78.84(24.41)$ & $75.96(20.70)$ & $65.86(17.97)$ \\
\hline
\end{tabular}




\begin{tabular}{|l|l|l|l|l|}
\hline $\begin{array}{l}\text { Spelling-to-sound } \\
\text { pseudo-words }\end{array}$ & correspondences of & $83.21(12.77)$ & $74.12(22.83)$ & $72.02(24.74)$ \\
\hline
\end{tabular}

Descriptive Statistics: Mean Percentage Scores by Grade and Task-Hebrew L1 Pupils

\begin{tabular}{|l|l|l|l|}
\hline & $\begin{array}{l}2^{\text {nd }} \text { grade M } \\
(\mathrm{SD})\end{array}$ & $\begin{array}{l}3^{\text {rd }} \text { grade M } \\
(\mathrm{SD})\end{array}$ & $\begin{array}{l}4^{\text {th }} \text { grade M } \\
(\mathrm{SD})\end{array}$ \\
\hline Real word recognition & $89.61(5.18)$ & $96.50(5.29)$ & $98.57(2.34)$ \\
\hline Auditory discrimination of pseudo-words & $85.89(13.53)$ & $83.88(16.86)$ & $96.03(6.69)$ \\
\hline Pronunciation of written pseudo-words & $93.27(9.00)$ & $95.62(8.35)$ & $94.64(6.42)$ \\
\hline $\begin{array}{l}\text { Spelling-to-sound correspondences } \\
\text { pseudo-words }\end{array}$ & $82.51(14.11)$ & $90.00(15.12)$ & $89.61(16.28)$ \\
\hline
\end{tabular}

Descriptive statistics: Mean Percentage Scores by Grade and Task-Arabic L1 Pupils

Total mean score for Arabic L1 pupils $=91.34 \%$ (7.10). For the Hebrew L1 pupils the score was significantly lower - 75.84\% (13.24). In order to explore the effect of mother tongue and grade on spelling accuracy, a series of repeated measure 3-way ANOVA analyses was made, with language and grade as between-subject factors, and task as within-subject factor. The results showed main effect for mother tongue $F(1,70)=$ 40.32, $p<.001, \eta^{2}=.37$, and two interactions: a) for mother tongue and grade $\mathrm{F}(2,70)=$ 3.37, $p=.04, \eta \mathrm{P}^{2}=.09$. According to this interaction, the mean score of Arabic L1 pupils is significantly higher than that of Hebrew L1 pupils in $3^{\text {rd }}$ and $4^{\text {th }}$ grade, but not in Grade 2. b) Interaction between mother tongue and task $F(3,210)=5.45, p=.001, \eta \mathrm{P}^{2}=$. 07, according to which the mean score for Arabic L1 pupils was significantly higher in all tasks except for auditory discrimination, in which no significant differences were found.

The second question examined accurate spelling of four novel phonemes targeted (guttural: /H/, uvular-velar: /q/ and /ь/, and emphatic: /s/) at native Hebrew-speaking pupils in second, third, and fourth grade. Table 3 presents descriptive statistics of mean percentage scores for novel phonemes across tasks for Hebrew L1 pupils, and Table 4 presents descriptive statistics of mean percentage scores for novel phonemes across tasks among Arabic L1 pupils.

Table 3

\begin{tabular}{|c|c|c|c|}
\hline & $2^{\text {nd }}$ grade $\mathrm{M}(\mathrm{SD})$ & $3^{\text {rd }}$ grade $M(S D)$ & $4^{\text {th }}$ grade $\mathrm{M}(\mathrm{SD})$ \\
\hline Guttural (/H/) & $84.61(11.65)$ & $81.07(16.84)$ & $71.04(21.27)$ \\
\hline Uvular-velar (/q/) & $71.94(17.67)$ & $77.60(11.69)$ & $78.28(13.66)$ \\
\hline Uvular-velar (/ь/) & $80.28(15.69)$ & $77.62(13.36)$ & $63.94(15.12)$ \\
\hline Emphatic (/s/) & $79.48(16.87)$ & $75.55(14.40)$ & $71.79(14.44)$ \\
\hline
\end{tabular}

Descriptive Statistics: Mean Percentage Scores for Novel Phonemes across Grades-Hebrew L1 pupils 


\begin{tabular}{|l|l|l|l|}
\hline & $2^{\text {nd }}$ grade M (SD) & $3^{\text {rd }}$ grade M (SD) & $4^{\text {th }}$ grade M (SD) \\
\hline Guttural (/H/) & $87.33(7.14)$ & $94.11(7.84)$ & $96.63(6.40)$ \\
\hline Uvular-velar (/q/) & $93.66(6.98)$ & $88.23(10.00)$ & $97.48(4.44)$ \\
\hline Uvular-velar (/B/) & $84.61(12.66)$ & $94.37(6.87)$ & $90.17(9.07)$ \\
\hline Emphatic (/s/) & $87.18(8.80)$ & $90.00(7.20)$ & $97.14(5.03)$ \\
\hline
\end{tabular}

Descriptive Statistics: Mean Percentage Scores for Novel Phonemes across Grades-Arabic L1 pupils

To explore the effect of mother tongue and grade/age on spelling accuracy of novel phonemes, a series of repeated measure 3-way ANOVA analyses with language and grade as between-subject factors, and phonemes as within-subject factor was performed. The results showed main effect for phonemes $\mathrm{F}(3,72)=3.01, p=.031, \mathrm{\eta}^{2}=$. 04 , and for language $\mathrm{F}(1,72)=3.86, p=.026, \mathrm{\eta}^{2}=.097$, as well as an interaction for phoneme, mother tongue and grade $\mathrm{F}(6,72)=3.92, p=.001, \mathrm{\eta}^{2}=.09$. Post hoc Bonferroni analysis indicated that native Arabic pupils spelled significantly better than their native Hebrew counterparts in regard to: 1 . Novel phoneme /H/ in fourth grade. 2. Novel phonemes / / / and /s/ in third and fourth grades. 3. Novel phoneme /q/ in second and fourth grades. Post hoc Bonferroni analysis also indicated that spelling accuracy of novel phonemes $/ \mathrm{H} / \mathrm{and} / \mathrm{B} /$ was significantly lower for native Hebrew pupils in the fourth grade than in the second grade. Total mean scores for phoneme /q/ (of both groups) were significantly higher than for $/ \mathrm{B} /$ in the fourth grade.

\section{Discussion}

The results among native Hebrew pupils show a spelling accuracy mean score of approximately $76 \%$ for all tasks in all grades. These results are encouraging. Previous studies conducted by Fragman \& Russak (2010) and Russak \& Fragman (2014) among native Hebrew pupils learning in a standard Hebrew junior high school found extremely low mean scores for spelling accuracy of novel phonemes in Arabic, ranging from $19 \%$ in the $8^{\text {th }}$ and $9^{\text {th }}$ grades to $25 \%$ in the $10^{\text {th }}$ grade; and an even lower mean score for general spelling accuracy of first-year words (11\%). Moreover, while the results for real-word recognition were approximately $66 \%$ from $8^{\text {th }}$ to $10^{\text {th }}$ Hebrew L1 grades, the results, using the identical words in the current study, were $75 \%$ for Hebrew L1 second graders of Neve Shalom. In addition, among Hebrew L1 pupils learning in a non-bilingual setting, it was found that scores for auditory discrimination decreased in the tenth grade, after four years of Arabic studies. ${ }^{45}$ One possible explanation suggested by the researchers was the limited exposure to Arabic-only three hours per week from seventh to tenth grade, which is inadequate for meaningful learning of Arabic among Hebrew L1 pupils. However, the fact that scores for auditory discrimination decreased over time suggested that number of hours of exposure to Arabic was not the only factor that affected the low scores of the pupils. Another possible explanation referred to insufficient teacher training. It appeared that most teachers for Arabic in Hebrew schools were (and still are) Hebrew L1 speakers, who admitted being unable to correctly pronounce some of the novel phonemes in Arabic, 
and lack the competence of speaking Arabic, therefore they conduct their lessons in Hebrew. This fact suggests that Hebrew L1 pupils learning Arabic as a second/foreign language in the general educational system are hardly exposed to Arabic even during Arabic lessons as a result of poor teacher competence and training. The results of Donitsa-Schmidt et al. (2004), which found no improvement in spoken Arabic vernacular proficiency among Hebrew L1 pupils from $4^{\text {th }}$ to $6^{\text {th }}$ grades also indicated insufficient exposure to Arabic (two hours per week), but also referred to the lack of pedagogical mentoring for Arabic teachers, who were not trained to teach spoken Arabic professionally, and did not know how to make the discussion work. ${ }^{46}$ Therefore, most of the pedagogical activities were intuitively implemented by the teachers from one lesson to the other. ${ }^{47}$ The results of another study ${ }^{48}$ among native Hebrew students learning Arabic for academic purposes at a university also supported this notion, indicating significant improvement in oral language performance towards the end of the second year only after specific pedagogical activities for improving listening skills were introduced by the academic stuff in the second year of the Arabic Studies programme. In other words, as much as length of exposure is a fundamental factor in the study of an additional language, much attention must also be paid to teacher training and to various aspects of instruction and pedagogical activities during second/ foreign language lessons in order to develop specific skills meaningfully.

Studies of children who are only partially bilingual (like those in the present study) have revealed different levels of second language proficiency among different groups. ${ }^{49}$ However, researchers agree that strong bilingual education programmes ${ }^{50}$ that actively promote learning of and in L1 and L2 is a prime education setting which facilitates language and literacy and positively influences cognitive development. ${ }^{51}$ Therefore, it seems that the explanation for the high scores of the native Hebrew pupils, mainly of the $2^{\text {nd }}$ grade (who are still at the initial stages of language acquisition), stems not merely from the number of hours of exposure to Arabic, but from something much deeper. Being the first of a series of studies focusing on linguistic outcomes in Arabic-Hebrew bilingual setting in Israel, with limited number of participants, it is difficult to point out one factor only that affected the linguistic proficiency of the pupils. Therefore, we assume that the high scores for spelling accuracy of novel phonemes in the current study reflect a combination of several factors upon which the unique model of Neve Shalomis based, i.e. full mutual learning of Arabic and Hebrew L1 pupils in all lessons, and learning both languages, from $1^{\text {st }}$ grade, without translation. The system appears to also have a major effect in regard to acquisition of novel phonemes.

Furthermore, the results of this study have found no significant difference in spelling accuracy for the four novel phonemes among Hebrew L1 pupils in the $2^{\text {nd }}$ grade. This suggests that the pedagogical model of Neve Shalom enabled a successful linguistic foundation for the $2^{\text {nd }}$ grade pupils involved in this study. In addition, our results also suggest that early exposure to Arabic in the appropriate bilingual setting-as described above-can also enhance linguistic knowledge.

It should be noted, that the results for spelling accuracy among the Arabic L1 pupils are even higher than those reported in previous studies..$^{52}$ This may also indicate that children who learn an additional language with similar phonological structure and alphabetic orthographic system to their native tongue may have an advantage over their monolingual counterparts in L1 acquisition. ${ }^{53}$ It also reinforces the significance of 
the Neve Shalom model in promoting good relationships between Arabic and Hebrew L1 speakers in Israel ${ }^{54}$ and improves spelling accuracy of novel phonemes in Arabic for Hebrew and Arabic L1 pupils alike.

It is our belief that native Hebrew speakers should be exposed to Arabic from an early age, in order to acquire equal proficiency in both languages, apart from the socio-political and educational aspects. ${ }^{55}$ The characteristics of bilingual settings should be explored in greater depth in order to consolidate models for L1-L2 learning for Arabic-Hebrew populations to become native-like. The State of Israel, rooted in Middle Eastern cultures, should strive for mutual learning of Arabic and Hebrew. This would reflect the multicultural Israeli society on one hand and embody the intention of bilingual education in Israel on the other.

\section{BIBLIOGRAPHY}

ABU-RABIA Salim \& TAHA Haitham, 2004, "Reading and Spelling Error Analysis of Native Arabic Dyslexic Readers" in Reading and Writing: An Interdisciplinary Journal, n 17, pp. 651-689.

ABU-RABIA Salim \& TAHA Haitham, 2006, "Phonological Errors Predominate in Arabic Spelling across Grades 1-9" in Journal of Psycholinguistic Research, $\mathrm{n}^{\circ}$ 35, pp. 167-188.

AzAiza Faisal, HeRTz-LAzARowitz Rachel, Shoham Meyrav, Amara Muhammad, MOR-SOMMERFELD Aura \& Ali Nohad, 2011, “Attitudes towards Bilingual Arab-Hebrew Education in Israel: A Comparative Study of Jewish and Arab Adults" in Language, Culture and Curriculum, $\mathrm{n}^{\circ} 24$, pp. 179-193.

BAKER Colin, 2011, Foundations of Bilingual Education and Bilingualism, $5^{\text {th }}$ ed., Multilingual Matters, Bristol, 512 P.

BeKerman Zvi, 2003, "Reshaping Conflict through School Ceremonial Events in Israeli PalestinianJewish Coeducation" in Anthropology \& Education Quarterly, n 34, pp. 205-224.

BEKERMAN Zvi, 2004, "Potential and Limitations of Multicultural Education in Conflict-Ridden Areas: Bilingual Palestinian-Jewish Schools in Israel” in Teacher College Record, $\mathrm{n}^{\circ}$ 106, pp. 574-610. BeKERMAn Zvi, 2009, “The Complexities of Teaching Historical Conflictual Narratives in Integrated Palestinian-Jewish Schools in Israel" in International Review of Education, ${ }^{\circ} 55$, pp. 235-250.

BEKERMAN Zvi, HABIB Ayala \& SHHADI Nader, 2011, “Jewish-Palestinian Integrated Education in Israel and Its Potential Influence on National and/or Ethnic Identities and Intergroup" in Journal of Ethnic and Migration Studies, $\mathrm{n}^{\circ}$ 37, pp. 389-405.

BEKERMAN Zvi \& HORENCZYK Gabriel, 2004, “Arab-Jewish Bilingual Coeducation in Israel: A Long Term Approach to Intergroup Conflict Resolution" in Journal of Social Issues, $\mathrm{n}^{\circ} 60, \mathrm{pp}$. 389-404.

BEKERMAN Zvi \& MAOZ Ifat, 2005, "Troubles with Identity: Obstacles to Coexistence Education in Conflict-Ridden Societies" in Identity: An International Journal of Theory and Research, $\mathrm{n}^{\circ} 5$, pp. 341-357. 
BEKERMAN Zvi \& NIR Adam, 2006, "Opportunities and Challenges in Integrated Education in Conflict-Ridden Societies" in International Focus Issue, ${ }^{\circ}$ 82, pp. 327-333.

BEKERMAN Zvi \& SHHADI Nader, 2003, “Palestinian-Jewish Bilingual Education in Israel: Its Influence on Cultural Identities and Its Impact on Intergroup Conflict" in Journal of Multilingual and Multicultural Development, $\mathrm{n}^{\circ}$ 24, pp. 473-484.

BENTIN Shlomo \& IBRAHIM Rafiq, 1996, "New Evidence for Phonological Processing during Visual Word Recognition: The Case of Arabic" in Journal of Experimental Psychology, n 22, pp. 309-323.

BERGENTOFT Rune, 1994, "Foreign Language Instruction: A Comparative Perspective" in LAMBERT Richard D. (ed.), Language Planning Around the World: Contexts and Systematic Change, National Foreign Language Center, Washington DC, pp. 17-46.

BIALYSTOK Ellen, 2001, Bilingualism in Development: Language, Literacy, and Cognition, Cambridge University Press, New York, 288 p.

BialystoK Ellen, MajUMder Shilpi \& MARTIN Michelle, 2003, "Developing Phonological Awareness: Is there a Bilingual Advantage?" in Applied Psycholinguistics, ${ }^{\circ}$ 24, pp. 27-44.

BRISK Maria Estela \& PROCTOR Patrick, 2012, "Challenges and Supports for English Language Learners in Bilingual Programmes” in HAKUTA Kenji \& SANTOS María (eds.) Understanding Language, Stanford University, pp. 115-122.

DA FonTOURA Helena \& SIEGEL Linda, 1995, "Reading Syntactic and Memory Skills of Portuguese-English Canadian Children" in Reading and Writing: An Interdisciplinary Journal, no 7, pp. 139-153.

DEFIOR Sylvia, MARTOS Francisco \& CARY Luz, 2002, "Differences in Reading Acquisition Development in Two Shallow orthographies: Portuguese and Spanish" in Applied Psycholinguistics, $\mathrm{n}^{\circ} 23$, pp. 135-148.

DENTON Carolyn, HASBRouk Jan, WEAVER Laurie \& Riccio chinthia, 2000, "What Do We Know about Phonological Awareness in Spanish?" in Reading Psychology, n² 21, pp. 335-352.

DONITSA-SCHMIDT Smadar, INBAR ofra \& SHOHAMY Elana, 2004, “The Effects of Teaching Spoken Arabic on Students' Attitudes and Motivation in Israel" in The Modern Language Journal, $\mathrm{n}^{\circ} 88$, pp. 217-228.

DURGUNOGLU Aydin, NAGY William \& HANCIN-BHATT Barbara, 1993, “Cross-Language Transfer of Phonological Awareness" in Journal of Educational Psychology, $\mathrm{n}^{\circ}$ 85, pp. 453-465.

EHRI Linnea, 1993, “How English Orthography Influences Phonological Knowledge as Children Learn to Read and Spell" in ScHolES Robert J. (ed.), Literacy and Language Analysis, Lawrence Erlbaum, Hillsdale NJ, pp. 21-43.

EVIATAR zohar, IBRAHIM Rafiq \& GANAYIM Deia, 2004, “Orthography and the Hemispheres: Visual and Linguistic Aspects” in Neuropsychology, $\mathrm{n}^{\circ} 18, \mathrm{pp} .174-184$.

FEUERVERGER Grace, 2001, Oasis of Dreams: Teaching and Learning Peace in a Jewish-Palestinian Village in Israel, Routledge Falmer, New York \& London, $218 \mathrm{p}$.

Fragman Alon, 2014, "Spelling Proficiency of Novel Phonemes in Arabic among Native Hebrew Academic Students" in Athens Journal of Philology, $\mathrm{n}^{\circ}$ 1, pp. 33-44.

FRAGMAN Alon \& RUSSAK Susie, 2010, "Qualitative Analysis of Spelling Errors in Arabic as a Foreign Language among Native Hebrew Students in Israel" in Arabele2009: Teaching and Learning the Arabic Language, pp. 103-114. 
HAMADA Megumi \& KODA Keiko, 2008, "Influence of First Language Orthographic Experience on Second Language Decoding and Word Learning" in Language Learning, $\mathrm{n}^{\circ} 58$, pp. 1-31.

Ho connie suk-Han \& BRYANT Peter, 1999, "Different Visual Skills Are Important in Learning to Read English and Chinese" in Educational and Child Psychology, $\mathrm{n}^{\circ}$ 16, pp. 4-14.

IBRAHIM Rafiq \& EVIATAR zohar, 2009, "Language Status and Hemispheric Involvement in Reading: Evidence from Trilingual Arabic Speakers Tested in Arabic, Hebrew, and English" in Neuropsychology, $\mathrm{n}^{\circ} 23$, pp. 240-254.

IBRAHIM Rafiq \& EVIATAR zohar, 2012, "The Contribution of the Two Hemispheres to Lexical Decision in Different Languages" in Behavioral and Brain Functions, $\mathrm{n}^{\circ}$ 8, pp. 2-15.

IBRAHIM Rafiq, EVIATAR zohar \& AHARON PERETZ Judith, 2002, "The Characteristics of the Arabic Orthography Slow Its Cognitive Processing" in Neuropsychology, ${ }^{\circ}$ 16, pp. 322-326.

IBRAHIM Rafiq, EVIATAR zohar \& AHARON PERETZ Judith, 2007, "Meta-Linguistic Awareness and Reading Performance: A Cross-Language Comparison" in Journal of Psycholinguistic Research, $\mathrm{n}^{\circ} 36$, pp. 297-317.

IBRAHIM Rafiq, SHIBEL Suha \& HERTZ-LAZAROWITZ Rachel, 2014, “The Complex Nature of Text Reading Difficulties: The Case of Bilingual Children" in Psychology, n 5, pp. 1911-1921.

JONG Peter \& VAN der LEIJ Ariyan, 2002, "Effects of Phonological Abilities and Linguistic Comprehension on the Development of Reading" in Scientific Studies of Reading, $\mathrm{n}^{\circ}$ 6, pp. 51-77.

KUHARA-KojImA Keikz, HATANo Giyoo, SAITO Heirofumi \& HAEBARA Tomokazu, 1996, "Vocalization Latencies of Skilled and Less Skilled Comprehenders for Words Written in Hiragana and Kanji" in Reading Research Quarterly, n 31, pp. 158-171.

LI wenling, ANDERSON Richard, NAGY william \& ZHANG Houcan, 2002, "Facets of Metalinguisitc Awareness That Contribute to Chinese Literacy" in LI wenling, GAFFINEY Janet S. \& PACKARD Jerome L. (eds.), Chinese Children's Reading Acquisition: Theoretical and Pedagogical Issues, Kluwer, Boston, pp. 87-106.

LIBERMAN Isabelle \& LIBERMAN Alvin, 1990, "Whole Language vs. Code Emphasis: Underlying Assumptions and Their Implications for Reading Instruction" in Annals of Dyslexia, $\mathrm{n}^{\circ} 40$, pp. 51-76.

McBRIDE-CHANG Catherine, 1998, “The Development of Invented Spelling” in Early Education \& Development, $\mathrm{n}^{\circ}$ 9, pp. 147-160.

McBRIDE-CHANG Catherine, BIALYSTOK Ellen, CHONG Karen \& Li Yanping, 2004, "Levels of Phonological Awareness in Three Cultures" in Journal of Experimental Child Psychology, $\mathrm{n}^{\circ}$ 89, pp. 93-111.

MENDEL Yonatan, 2013, “A Sentimental-Free Arabic: On the Creation of the Israeli Accelerated Arabic Language Studies Programme" in Middle Eastern Studies, ${ }^{\circ}$ 49, pp. 383-401.

MoNTVILlE Joseph, 1998, “Neve Shalom: A Model of Arab-Israeli Coexistence?” in Middle East Quarterly, n5, pp. 21-27.

MOR-SOMMERFELD Aura, 2002, "Language Mosaic-Developing Literacy in a Second-New Language: A New Perspective" in Reading Literacy and Language, n³ 36(3), pp. 99-105.

MOR-SOMMERFELD Aura, 2005, "Bilingual Education in Areas of Conflict-Bridging and Sharing" in Race Equality Teaching, vol. 24, $\mathrm{n}^{\circ} 1$, pp. 31-42. 
MOR-SOMMERFELD Aura, AZAIZA Faisal \& HERTZ-LAZAROWITZ rachel, 2007, "Into the Future-towards Bilingual Education in Israel" in Education, Citizenship and Social Justice, $\mathrm{n}^{\circ} 2(1), \mathrm{pp} .5-22$.

MOR-SOMMERFELD Aura \& ADIV Ehud, 2008, "Education in the Age of American Globalization. Israel: From Critical Pedagogy to Political Pedagogy" in HILL Dave (ed.), The Rich World and the Impoverishment of Education: Diminishing Democracy, Equity and Workers' Rights, Routledge, New York.

NASSER Ilham, 2014, "Perspectives of Palestinian and Jewish Parents in Israel on Bilingual Education" in International Journal of Bilingual Education and Bilingualism, $\mathrm{n}^{\circ} 14, \mathrm{pp} .301-318$.

PATEL Tanya, SNOWLING Margaret and Jong Peter (de), 2004, “A Cross-Language Comparison of Children Learning to Read in English and Dutch" in Journal of Educational Psychology, $\mathrm{n}^{\circ}$ 96, pp. 785-797.

PERfETTI charles, 2013, "Representations and Awareness in the Acquisition of Reading Competence" in REIBEN Laurence \& PERFETTI charles (eds.), Learning to Read: Basic Research and Its Implications, Routledge, New York, pp. 33-44.

RUSSAK Susie \& FRAGMAN Alon, 2014, "Spelling Development in Arabic as a Foreign Language among Native Hebrew Speaking Pupils" in Reading and Writing: An Interdisciplinary Journal, $\mathrm{n}^{\circ} 27(2)$, pp. 359-381.

SAIEGH-HADDAD Elinor, 2003, "Linguistic Distance and Initial Reading Acquisition: The Case of Arabic Diglossia" in Applied Psycholinguistics, $\mathrm{n}^{\circ} 24$, pp. 431-451.

SAIEGH-HADDAD Elinor, 2004, "The Impact of Phonemic and Lexical Distance on the Phonological Analysis of Words and Pseudowords in a Diglossic Context" in Applied Psycholinguistics, $\mathrm{n}^{\circ} 25$, pp. 495-512.

SAIEGH-HADDAD Elinor, 2005, "Correlates of Reading Fluency in Arabic: Diglossic and Orthographic Factors" in Reading and Writing: An Interdisciplinary Journal, $\mathrm{n}^{\circ}$ 18, pp. 559-582.

SAIEGH-HADDAD Elinor, 2007, "Linguistic Constraints on Children's Ability Phonemes in Arabic" in Applied Psycholinguistics, $\mathrm{n}^{\circ}$ 28, pp. 607-626.

SCHWARTZ Mila, MOR-SOMMERFELD Aura \& LEIKIN Mark, 2010, "Facing Bilingual Education:

Kindergarten Teachers' Attitudes, Strategies and Challenges" in Language Awareness, $\mathrm{n}^{\circ} 19$, pp. 187-203.

SHIMron Joseph, 2006, Reading Hebrew: The Language and the Psychology of Reading It, Erlbaum, Mahwah NJ, 205 p.

SIEGEL Linda \& ABU RABIA Salim, 2006, "Interests and Dilemmas in Bilingual Education Research". Paper presented at the conference "Into the Future: toward Bilingual Education in Israel", Haifa, May 2006, http://www.jceps.com/wp-content/uploads/PDFs/06-2-08.pdf.

SLAVIN Robert \& CALDERON Margarita (eds.), 2001, Effective Programs for Latino Students, Lawrence Erlbaum Associates, New Jersey, 394 P.

So Dominica \& SIEGEL Linda, 1997, "Learning to Read Chinese: Semantic, Syntactic, Phonological and Short-Term Memory Skills in Normally Achieving and Poor Chinese Readers" in Reading and Writing: An Interdisciplinary Journal, $\mathrm{n}^{\circ}$ 9, pp. 1-21.

STEPHAN Cookie white \& HERTZ-LAZAROWITZ Rachel, ZELNIKER Tamar \& STEPHAN walter, 2004, "Introduction to Improving Arab-Jewish Relations in Israel: Theory and Practice in Coexistence Educational Programs" in Journal of social issues, $n^{\circ} 60$, pp. 237-252. 
SVIRSKY Marcelo \& MOR-SOMMERFELD Aura, 2012, "Interculturalism and Pendulum of Identity" in Intercultural Education, $\mathrm{n}^{\circ}$ 23(6), pp. 513-525.

TREIMAN Rebecca, 1992, “The Role of Intrasyllabic Units in Learning to Read and Spell” in GOUGH Phillip, EHRI Linnea \& TREIMAN rebecca (eds.), Reading Acquisition, Erlbaum, Hillsdale, NJ, pp. 65-106.

UhLmANN Allon, 2011, "Policy Implications of Arabic Instruction in Israeli Hebrew Schools" in Human Organization, $\mathrm{n}^{\circ}$ 70, pp. 97-105.

UR Penny, 1981, Discussions That Work, Cambridge University Press, Cambridge, 122 p.

YopP Hallie Kay, 1988, “The Validity and Reliability of Phonemic Awareness Tests" in Reading Research Quarterly, n²3, pp. 159-177.

ZEMBYLAS Michalinos \& BEKERMAN Zvi, 2011, "The Work of Mourning in the Bilingual Schools of Israel: Ambivalent Emotions and the Risks of Seeking Mutual Respect and Understanding" in British Journal of Sociology of Education, $\mathrm{n}^{\circ} 32$, pp. 583-601.

ZhANG sulan \& Perfetti charles, 1993, "The Tongue-Twister Effect in Reading Chinese" in Journal of Experimental Psychology: Learning, Memory, and Cognition, $\mathrm{n}^{\circ}$ 19, pp. 1-12.

\section{NOTES}

1. The authors gratefully acknowledge the generosity and kindness of all members of the Neve Shalom/Wahat al-Salam/Oasis of Peace School, who enabled us to conduct our study.

2. MOR-SOMMERFELD, 2009.

3. FEUERVERGER, 2001.

4. Fragman, 2014; FRAGMAN \& RUSSAK, 2010; RUSSAK \& FRAGMAN, 2014.

5. Majority-minority language relationships in Israel are complicated: Hebrew is the majority language in Israel, but Arabic is the majority language of the Middle East where Hebrew is considered a minority language.

6. MENDEL, 2013.

7. FEUERVERGER, 2001.

8. F EUERVERGER, 2001; BEKERMAN, 2003; MOR-SOMMERFELD, 2005; SVIRSKY \& MOR-SOMMERFELD, 2012.

9. AzAizA et al., 2011.

10. MOR-SOMMERFELD, 2002.

11. MOR-SOMMERFELD, 2005.

12. MOR-SOMMERFELD, 2007.

13. Azaiza et al., 2011; BeKerman, 2003, 2004, 2009; BeKerman, Habib \& ShHAdi, 2011; BEKERMAN \& HORENCZYK, 2004; BEKERMAN \& NIR, 2006; BEKERMAN \& SHHADI, 2003; MONTVIlle, 1998; NASEer, 2014; STEPHAN, HERTZ-LAZAROWITZ, ZELNIKER \& STEPHAN, 2004; ZEMBYLAS \& BEKERMAN, 2011.

14. e.g. B EKERMAN \& MAOZ, 2005; SLAVIN \& CALDERON, 2001; MOR-SOMMERFELD, 2002; SIEGEL \& ABU RABIA, 2006. 
15. MOR-SOMMERFELD, 2008.

16. BEKERMAN \& HORENCZYK, 2004.

17. BIALYSTOK, 2001.

18. BEKERMAN \& HORENCZYK, 2004.

19. IBRAHIM, SHIBEL \& HERTZ-LAZAROWITZ, 2014.

20. BiALySTOK, 2001.

21. BiAlystoK, MAJUMdER \& MARTin, 2003.

22. McBRIDE-CHANG et al., 2004.

23. BiALYSTOK, MAJUMder \& MARTin, 2003.

24. BIALYSTOK, 2001.

25. BAKER, 2011.

26. BRISK \& PROCTOR, 2012.

27. LIBERMAN \& LIBERMAN, 1990.

28. EHRI, 1993.

29. PATEL, SNOWLING \& JoNG, 2004.

30. Denton et al., 2000; Durgunoglu, NAGy \& HANCIN-BhatT, 1993.

31. DEFIOR, MARTOS \& CARY, 2002.

32. JONG \& VAN DER LEIJ,2002; PERFETTI, 2013.

33. Yopp, 1988; TREIMAN, 1992; DuRgunOGLu et al., 1993; McBRIDE-CHANG, 1998.

34. Abu Rabia \& TAHA, 2004, 2006; Bentin \& IBrahim, 1996; Eviatar, Ibrahim \& Ganayim, 2004; IBRAHIM \& EVIATAR, 2009, 2012; IBRAHIM, EVIATAR \& AHARON-PEREZ, 2002, 2007; SAIEGH-HADDAD, 2003, 2004, 2005, 2007.

35. DA FONTOURA \& SIEGEL, 1995.

36. Ho \& BryANT, 1999; Li et al., 2002; So \& SiEGEL, 1997; ZHANG \& PeRfETTI, 1993.

37. KuHARA-KojIMA et al., 1996.

38. HAMADA \& KODA, 2008.

39. RUSSAK \& FRAGMAN, 2014.

40. SHIMRON, 2006.

41. RUSSAK \& FRAGMAN, 2014.

42. BERGENTOFT, 1994.

43. UHLMANN, 2011.

44. RUSSAK \& FRAGMAN, 2014.

45. RUSSAK \& FRAGMAN, 2014.

46. UR, 1981.

47. DONITSA-SCHMIDT et al., 2004.

48. FRAGMAN, 2014.

49. BiALYSTOK, 2001.

50. BAKER, 2011. 
51. BRISK \& PROCTOR, 2012.

52. ABU RABIA \& TAHA, 2006.

53. BiALYSTOK, MAJUMDER \& MARTIN, 2003.

54. MOR-SOMMERfELD, 2002; BeKerman \& MAOZ, 2005; Siegel \& ABU RABiA, 2005; STEPHAN et al., 2004; ZEMBYLAS \& BEKERMAN, 2011.

55. MOR-SOMMERFELD, 2007.

\section{ABSTRACTS}

Previous studies of the Neve Shalom/Wahat al-Salam/Oasis of Peace Bilingual School have focused mainly on the socio-cultural and political aspects of the school. The current study explores spelling accuracy of novel phonemes. Four tasks were created for the $2^{\text {nd }}-4^{\text {th }}$ grades for the purpose of this study, all dealing with phonemic aspects and phoneme-grapheme correspondences. Compared with the poor results of previous studies dealing with spelling accuracy among Hebrew L1 pupils in non-bilingual settings, the results of the current study show significantly higher scores in all grades for all the tasks. It is assumed that the most significant factor affecting higher scores as of the second grade is the unique pedagogical setting implemented at Neve Shalom a few years ago. It advocates mutual learning of L1/L2 pupils mentored by L1 teachers without translation and without separate lessons for Hebrew and Arabic speakers, as had been previously accepted at Neve Shalom, and still is in other Arabic-Hebrew settings in Israel. The results of the current study may also indicate that early exposure to Arabic in a bilingual setting also enhances linguistic knowledge.

Les recherches antérieures menées à l'école élémentaire bilingue de Neve-Shalom avaient comme principal objectif l'étude des aspects socio-culturels et politiques de cette école. Cette recherche-ci a examiné l'épellation de phonèmes arabes inconnus parmi des locuteurs natifs de l'hébreu. L'étude comprenait quatre tâches destinées aux élèves de CE1-CM1, permettant d'examiner différents aspects du savoir phonémique et des relations graphème-phonème. En comparaison de recherches semblables au sein de locuteurs natifs de l'hébreu dans des écoles unilingues, les résultats dans cette étude étaient meilleurs dans les quatre tâches. Nous formulons l'hypothèse que la raison principale de ces excellents résultats serait à attribuer à la pédagogie unique de l'école bilingue à cette époque. Les principes de cette pédagogie étaient : un enseignement commun par une enseignante arabophone et une autre hébréophone dans chaque classe, à chaque cours, sans traduction et sans cours de langue distincts (comme cela se pratique habituellement dans la plupart des écoles bilingues). Les résultats de l'étude semblent révéler l'importance de l'exposition précoce à l'arabe dans un environnement bilingue comme moyen de renforcement du savoir linguistique des élèves. 
מחקרים קודמים שנעשו בבית הספר הדו-לשוני נוה שלום התמקדו בהיבטים סוציו-תרבותיים

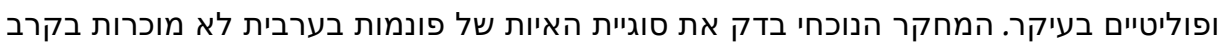

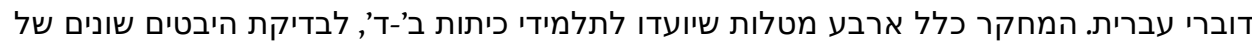

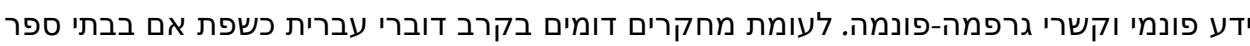

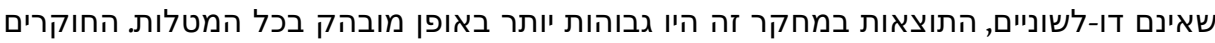

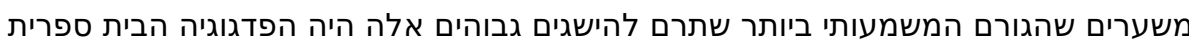

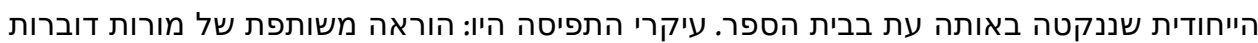

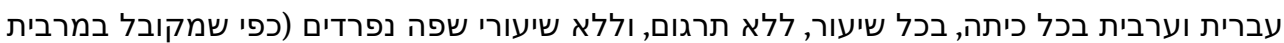

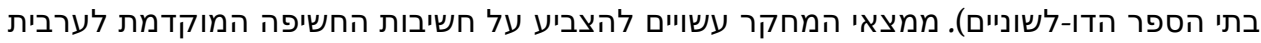
בסביבה דו-לשונית כאמצעי לחיזוק הידע הלשוני של התלמידים המידים.

INDEX

Mots-clés: École bilingue, épellation, arabe comme LV2

Keywords: Bilingual School, spelling accuracy, Arabic as a second language

בית ספר דו-לשוני, איות, ערבית כשפה שנייהמילות מפתח:

\section{AUTHORS}

\section{ALON FRAGMAN}

Open University, Ra'anana

\section{AURA MOR-SOMMERFELD}

University of Haifa, Goldsmiths University of London 